\title{
Archeological Investigations of the Caddo Lake Scholars Program at Caddo lake State Park, Harrison County, Texas, 1993-1995
}

Bob D. Skiles

Timothy K. Perttula

Heritage Research Center, Stephen F. Austin State University

Bo Nelson

Heritage Research Center, Stephen F. Austin State University

Mike Turner

Follow this and additional works at: https://scholarworks.sfasu.edu/ita

Part of the American Material Culture Commons, Archaeological Anthropology Commons, Environmental Studies Commons, Other American Studies Commons, Other Arts and Humanities Commons, Other History of Art, Architecture, and Archaeology Commons, and the United States History Commons

Tell us how this article helped you.

This Article is brought to you for free and open access by the Center for Regional Heritage Research at SFA ScholarWorks. It has been accepted for inclusion in Index of Texas Archaeology: Open Access Gray Literature from the Lone Star State by an authorized editor of SFA ScholarWorks. For more information, please contact cdsscholarworks@sfasu.edu. 
Archeological Investigations of the Caddo Lake Scholars Program at Caddo lake State Park, Harrison County, Texas, 1993-1995

\section{Creative Commons License}

(c) (i) (8)

This work is licensed under a Creative Commons Attribution-NonCommercial 4.0 International License 


\section{Archeological Investigations of the Caddo Lake Scholars Program at Caddo Lake State Park, Harrison County, Texas, 1993-1995.}

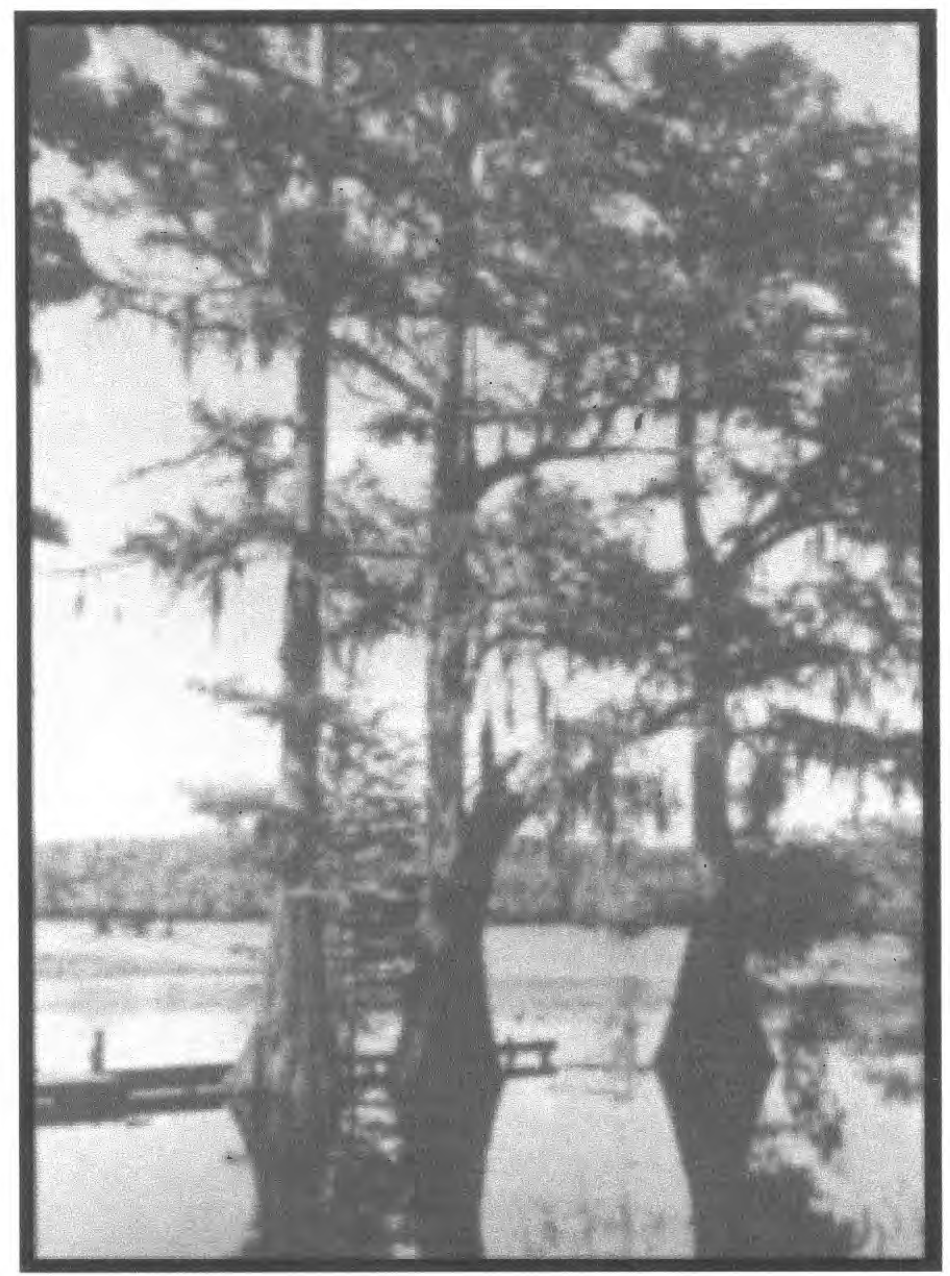

Friends of Northeast Texas Archaeology

Special Publication No. 2 (1995) 


\title{
Archeological Investigations of the Caddo Lake Scholars Program at Caddo Lake State Park, Harrison County, Texas, 1993-1995.
}

\author{
by \\ Bob D. Skiles \\ Timothy K. Perttula \\ Bo Nelson \\ and \\ Mike Turner
}
Caddo Lake Institute, Inc. 3703 Bridle Path
Marshall, Texas 75670
(903) 935-6115
and

Friends of Northeast Texas Archaeology

Texas Antiquities Permit No. 1310

Bob D. Skiles, Principal Investigator 


\section{TABLE OF CONTENTS}

I.IST OH FIGURES

PAGE ii

FOREWORD

PAGE iii

ABSTRACT

PAGE iv

ACKNOWI.FDGMEN'TS

PAGE $\quad V$

INTRODUCTION

PAGE 1

RESEARCH DESIGN

ENVIRONMENTAL SETTING

PAGE 3

ARCHE,OLOGICAL AND HISTORICAL BACKGROUND

PAGE 4

EXCAVATION OF SUSPECTED GRAVE FEATURE

PAGE 6

ARCHEOLOGICAL RECONNAISSANCE IN CADDO LAKE ST ATE PARK

PAGE 11

REFERFNCES CITED

PAGE 22

PAGE 26

\section{LIST OF FIGURES}

$\begin{array}{llll}\text { FIGURE } & \text { 1 - GENERAI, I OCATION MAP OF CADDO LAKE STATE PARK } & \text { PAGE } & 2 \\ \text { FIGURE } & 2 \text { - WETLANDS NEAR CADDO I.AKE STATE PARK } & \text { PAGE } & 5 \\ \text { FIGURF } & 3 \text { - PHOTO OH FEATURE BEFORE EXCAVATION } & \text { PAGE } & 13 \\ \text { FIGURE } & 4 \text { - SCALE DRAWING OF THE EXCAVATED FEATURE } & \text { PAGE } & 14 \\ \text { FIGURE } & 5 \text { - PHOTO OF FEATURE AFTER REMOVING VEGETATION } & \text { PAGE } & 15 \\ \text { FIGURE } & 6 \text { - PHOTO OH VOLUNTEER STUDENT SCREENING } & \text { PAGE } & 16 \\ \text { FIGURE } & 7 \text { - STUDENTS AND MENTORS MEASURING FEATURE } & \text { PAGE } & 18 \\ \text { FIGURE } & 8 \text { - STUDENT MAKING SCALE DRAWING OF FEATURE } & \text { PAGE } & 19 \\ \text { FIGURE } & 9 \text { - PHOTO OF FEATIRE AFTER EXCAVATION } & \text { PAGE } & 20 \\ \text { FIGURF. } 10 \text { - MAP OF SITE 4IHS582 } & \text { PAGE } & 24\end{array}$


An intrinsic aspect of the Caddo Lake Scholars Program is the study of the Caddoan peoples and their culture, both ancient and contemporary. The interest of the Caddo Lake Scholars Program and the cultural heritage of the Caddo Nation is completely consistent with our emphasis on learning about the natural science of the Caddo I ake bioregion. A study of the Caddoan people cannot be constrained to history or to the study of artifacts from their past; they are a living culture, and in our association with these Native Americans we hope to learn about them and from them concerning their material, intellectual, and spiritual culture.

Caddo Lake Institute (1995)

\title{
Foreword about the Caddo Lake Institute and the Caddo Lake Scholars Program
}

\author{
Timothy K. Perttula \\ Archeology Team I ceader
}

An important part of the mission of the Caddo Lake Institute and its Caddo Lake Scholars Program is the preservation and protection of the uniquc and irreplaceable cultural heritage of Caddo Lake and its bioregion (Perttula 1993a; Shellman 1993, 1995). The archeology and history teams of the Scholars Program are meeting these objectives by:

(a) offering archeological and historical education and training of students and potential mentors, (b) through fieldwork and research, identifying, assessing, and designating archeological, historical, and cultural resources of thc Caddo Iake bioregion, and (c) formulating and implementing strategies for protecting the hioregion's significant cultural resources.

Archeological investigations between 1993-1995 at Caddo State Park, reported herein, represent the initial efforts of the Caddo Lake Institute's archeology team to conduct an education/training program, as well as to begin the process of identifying important archeological and historical resourees in the Caddo Lake Basin. The archeology team will undertake several archeological projects in 1995-1996 in the Caddo Lake bioregion, particularly in the RAMSAR Treaty lands (Caddo Lake Wildlife Management Area) and on adjoining tracts of private land. Students and mentors from the consortium of Caddo Lake Seholars Program universities and schools are invited to participate in our archeological efforts, which will represent the first concerted and long-term study of the bioregion's cultural environment. 


\begin{abstract}
The Caddo Lake Scholars Program is a multidisciplinary, intercollegiate consortium of citizens, educators, scientists, and students from homes, agencies, universitics, colleges, and schools of the Caddo Lake bioregion who are interested in studying and conscrving this unique ecosystem. The Caddo Lake Scholars Program is administered by the Caddo Lake Institute, Inc, a not for profit research corporation established through the initiative and beneficence of Mr. Don Henley. In the fall of 1993, several avocational and professional archeologists, working in conjunction with the Caddo Lake Scholars Program, began a voluntary cultural resource assessment of Caddo Lake State Park. The purpose of this study was twofold: 1) to provide the Caddo Lake Scholars Program students an opportunity to participate in an archeological project; and 2) to provide the Texas Parks and Wildlife Department with baseline archeological data useful in promulgating a management plan for Caddo Lake State Park. This report details the voluntary archeological survey and testing work carried out in the park since the inception of the program in October 1993
\end{abstract}




\section{Acknowledgments}

This work reported herein could not have been completed without the assistance of numerous persons who volunteered their time to hclp. We especially thank Mr. Don IIenley who was responsible for establishment of the Caddo Lake Scholars Program. Through the on-going work of the Caddo Lake Institute, we believe that the unique values of Caddo Lake (that Mr. Henley and other dedicated Mentors of the (addo Lake Scholars Program appreciated as youths) will be rccognized and conserved for the benefit of future generations. Also, we wish to thank the stalwart lcaders of the Caddo Lake Institute, Dwight K. Shellman, Jr., and Sara Kneipp, for their enlightened interest in the cultural history of the Caddo Lake region, and their tireless efforts in supporting, planning and organizing the Discovery Day events so that Caddo people and archeology played important roles. The events benefited greatly from the advice and participation of Mary Cecile Cartcr, cultural liaison for the Caddo Indian Nation in Oklahoma, and Rufus Davis, chief of the Adaes Tribe of Louisiana. We are very grateful for the herculean efforts of many others who contributcd to the success of the archeology discovery event, including: Dr. David Bieler (Centenary College), Dr. Herman Gibson (Wiley College), Mr. Ray Hubbard, III (U.S. Iorest Service), Mrs. Velicia Hubbard (U.S. Forest Service), Mr. Bo Nelson (Northeast Texas Archeological Society), Mr. Tommy Pritchard (Texas Parks and Wildlife Department), and Mr. Mike Turner (Northeast Texas Archeological Society).

Although too numerous to cite individually, students and mentors from several universities and colleges participated in the cxcavation and Discovery Day events. We are thankful to all, but especially grateful for the assistancc of Mrs. Claire Gibson (Wiley College, who kept notes and wrote a class paper on the event) and Ms. Amber Emery (East Texas Baptist University, who prepared the scale drawing of the excavated feature appearing herein as Figure 4)

The survey fieldwork was carried out primarily through the voluntary efforts of Bo Nelson, Tom Speir, and Mike Turner of the Northeast 'lexas Archeological Society, undcr the supervision of Perttula and Skiles. The project could not have succeeded without their steadfast support and participation.

Perttula also thanks Dr. Kathleen Byrd, then Louisiana State Archeologist, for providing site forms and information about archeological sites along James Bayou and around Caddo Lake in Louisiana, as well as Jacques Bagur and Claude McCrocklin for sharing archeological and historical sources and findings concerning Caddo Lake and the nineteenth century Caddo Indian villagc.

Authors of sections in this report are cited under the respective section headings; Skiles was also responsible for authoring the unattributed sections and for production of the report. 


\section{Introduction}

\section{Statement of the Problem}

No cultural resource investigations had been carried out within Caddo Lake State Park (Figure 1) prior to those reported herein. Although numerous archeological projects have been conducted in the surrounding region, the archeology of the park is unknown. 'The Texas Parks and Wildlife Department (TPWD) has need of specific data on the types and distributions of cultural resources within the park boundaries to develop an effective management plan to protect, preserve, rcstore, and/or interprel the resources for the users of the park.

Over the past decadc, Northeast Texas has been experiencing an upsurge in incidents of vandalism aimed at archeological sites. In the past, these incidents have mainly involved individuals looting prehistoric cemeteries on private lands seeking artifacts for personal collections, or for sale to collectors. In recent years, there have been a disconcerting number of incidents involving commercial graverobbing at sites on public lands, and at remote and abandoncd historic cemeteries. These destructive and reprehensible acts have been perpetrated by persons sceking collectible items of monetary valuc from graves (e.g., aboriginal pottery, Civil War military insignia, porcelain doll parts, buttons, jewelry, gold teeth, etc).

In the case of the historic comcteries, the advent of relatively inexpensive and sophisticated electronic detection equipment has lead to this abhorrent form of "treasurehunting" spreading at an alarming rate. In the long run, educating the public (law enforcement officers, landowners, and a new generation of students) about the cultural and historical values of such "lost" resources, and to the great destruction causcd by the rampant digging of "treasurehunters," will be the only effective means of protecting cultural resource sites located in remote areas. To datc, though, cven the resources located in urban public places and parks have not been immune from the bane of treasurchunting.

Prior to initiation of this survey, a densely thicketed area across the park road from the parking lot of the Recreation Building and playground had been pointed out to the Park Superintendent as possibly the location of an early historic cemetery. Some local informants had suggested that this was the burial place of the early settlers and inhabitants of Port Caddo.

The Park Supcrintendent's examination at the reported location discovered a rectangular concrete border, similar in appearance to those that can be observed surrounding grave plots in many of the rural cemeteries throughout Northeast Texas. At some time within the past few years, surreptitious digging had occured within the concrete border. A pit was noted within the concrete border, and a corresponding backdirt pile was situated beside the feature. This digging had occured without the knowledge of park authorities, and had the apparent signature of graverobbing. Consequently, there was a need to determine, through archcological investigation, whether the feature was a grave. If it proved to be a grave, then other unmarked graves would likely exist ncarby, and this would bear importantly upon how the area must be managed by TPWD in the future. 


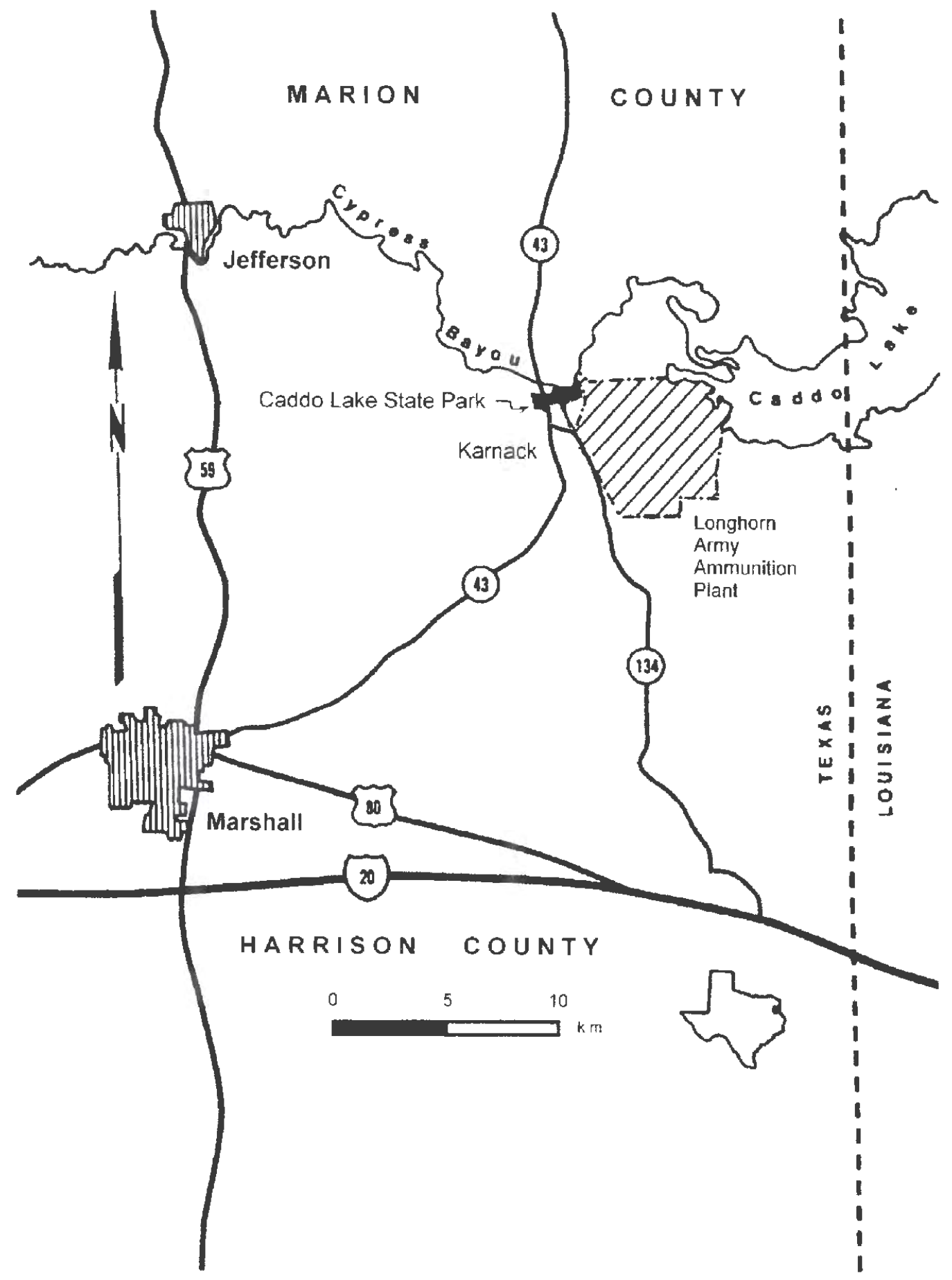

Figure 1. General location map of Caddo Lake State Park, Harrison County, Texas (adapted from Cliff et al. 1995: Figure 1). 


\section{Statement of the Opportunities}

The Caddo Lake Scholars Program had a "Discovery Day" public event scheduled at Caddo Lake State Park on Saturday, 23 October 1993. The event ivas to be held in conjunction with the annual clean up of Caddo Lake traditionally involving 2,000 or more volunteers. The purpose of the public event was to provide students of the 14 colleges and universities involved in the intercollegiate Caddo Iake Scholars Program opportunities to demonstrate the diversity of the environmental and cultural resources of this unique biorcgion through projects at "Discovery Sites" throughout the park. Among the participants in this event were Native American, federal, state and local officials, including: Mary Cecile Carter, cultural liaison of the Caddo Indian Nation in Oklahoma, and Rufus Davis, chief of the Adaes Tribe of Louisiana, Governor Ann Richards, an under-Secretary of Interior, and the U. S. Congressional Represcntatives from the respcctive districts in l'exas and Louisiana, containing Caddo Lake.

Conscquently, this feature, located immediately across the park road from most of the planncd public events, presented a convenient location for the archeology practicum. The practicum presented an opportunity: 1) to demonstrate the value of archeological techniques and cultural resources to an influential and diverse audience at the scheduled Discovery Day event (i. e., through interpretive displays and lectures at the site of what had been suspected to be a looted grave), and 2) to produce information useful in management of the park.

\section{Research Design}

The primary research qucstion addressed by the excavation of the fcature was: "Was this location a grave?" If the concrete-bordcred feature was determined to have becn a gravesite, then there would be a high probability of other interments being present in the vicinity. In that case, a suite of secondary research questions would need to be addressed: "Are other graves present? How many? Where are they located"" Knowing whether a grave or cemetery existed at this location would be important data needed for management of the park. If graves were located in the arca, then reconstruction, preservation, and interpretive efforts may be warranted in a management plan to ensure that such important cultural resources are protccted and properly interpreted for the benefit of the park users and the public at large.

Recovery of certain classes of artifacts, alone or in combination with other types of evidence from the feature, was expected to be certain indicators of a grave, for example: 1) grave marker fragments; 2) a deep, reclangular, vertical-sided, flat-bottomed pil aligned parallel with, and within, the concretc border; 3) coffin remnants and hardware; 4) clothing fasteners and personal items of adornment; and 5) human bones and bone fragments.

For the archcological reconnaissance of the park as a whole, a broad research question was posed: "What is the number, location and type of cultural resource sites within the park?" If cultural resources could be locatcd in the park, initial assessment of their eligibility for designation as State Archeological Landmarks would be made for TPWD. 
Although these were rather basic research questions, posing them provided a useful teaching vehicle for the students involved. Acquiring the answers to them would provide the first archeological data set for Caddo Lakc State Park and a contribution toward development of a management plan that can address the cultural resources located within the park.

The remainder of this report is presented in four scctions, as follows: 1) a general environmcntal setting for the study area, 2) a general archeological and historical background of the Caddo Lake State Park vicinity, 3) a report on the excavation of the suspected grave feature, and 4) a report on the results of the archeological reconnaissance within the park and vicinity.

\title{
Environmental Setting
}

\author{
Timothy K. Perttula and Bob D. Skiles
}

Caddo Lake State Park lics within the Piney Woods vegetation rcgion of the West Gulf Coastal Plain physiographic province (Diamond el al. 1987). The area in modern times has a humid subtropical climate with mild temperatures except during the summer when it is hot and humid, and precipitation ranges generally between $110-130 \mathrm{~cm}$.

Caddo I ake probably formed about two centuries ago when growth of the "Great Raft" on the Red River dammed the outlet of Big Cypress Bayou. This natural impoundment of the lower portion of Big Cypress Bayou valley was partially drained by early engineering efforts to remove the Great Raft to improve navigation on Red River. Rcmoval of the raft caused progressive improvement in drainagc of the Big Cypress Bayou valley and a concomitant lowering of lake levels that interfered with navigation to Jefferson. The lake level has since been stabilized by a dam built in 1920. The impoundment of Caddo Lake has created broad alluvial flats/terraces and marshy bottomlands along Big Cypress Bayou at the northern margins of the park (Figure 2, cf. Albertson and Dunbar 1993:Plates 6 and 7). The remainder of the park is marked by dissected and eroded uplands and valley slopes of Tertiary-age Wilcox and Reklaw Formation sands and clays. Bascd on the work of Peter and Stiles-Hanson (1990), dissected uplands and alluvial bottomlands are the only two environmental zones occuring in the Caddo Lake State Park vicinity. The investigations discussed in this report were located in the dissected uplands zone.

The dissected uplands in the park range in elevation from 200-340 fcct amsl, and they slope to the north and north-northwest towards the Big Cypress Bayou alluvial flats. The highest elevations in the park (above 300 feet amsl) are identified as the Reklaw Formation, with the remainder of the uplands belonging to the Wilcox Formation (Albertson and Dunbar 1993). The dissected upland zonc is thickly wooded with pine, along with various hardwoods (oaks, elms, pecan, and sweetgum) as part of the closed canopy forest (Peter and Stiles-l lanson 1990), and ground surface visibility is obscured by pine needles and leaves. Dissected upland soils in the park are principally deep, very fine sandy loams, but due to historic erosion (mainly from carly clearcutting of timber) the decper soils are preserved only in patchcs, and some areas of the park now cither have shallow (less than $50 \mathrm{~cm}$ ) very fine sandy loam sediments or the argillic B-horizon is exposed at the surface. 


\section{WETLANDS AND CADDO LAKE STATE PARK}

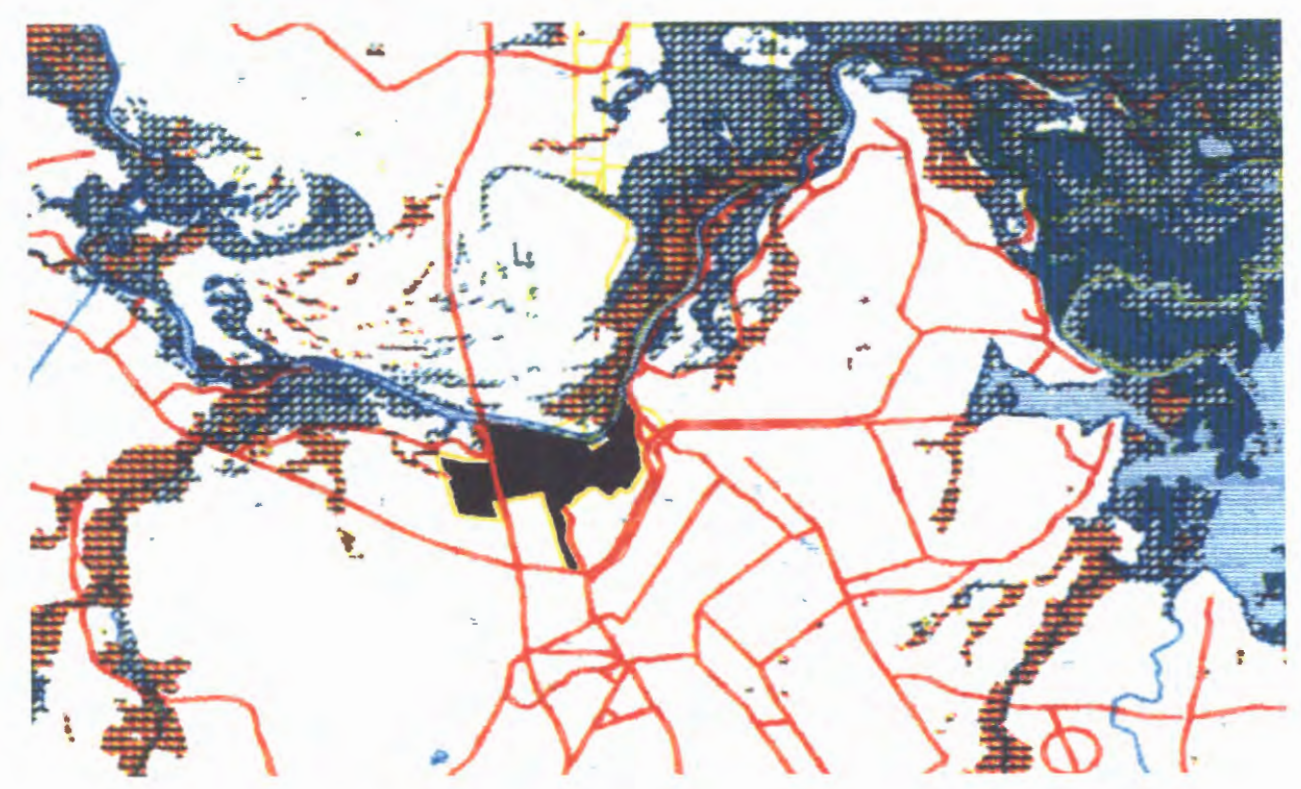

KEY

$\begin{aligned} \text { Black } & =\text { Caddo Lake State Park } \\ \text { Red } & =\text { Roadways } \\ \text { Blue } & =\text { Water } \\ \text { Yellow } & =\text { Administrative Boundaries } \\ \text { Green } & =\text { Emergents (grasses) } \\ \text { Red/Brown Stippled } & =\text { Bottomland Hardwoods } \\ \text { Dark Blue Stippled } & =\text { Cypress Forests (perm. flooded) } \\ \text { Gray/Green Stippled } & =\text { Cypress Forests }\end{aligned}$

Figure 2. Wetlands in the vicinity of Caddo Lake State Park (adapted from a map compiled by the National Wetlands Inventory from NASA color infrared aerial photography, 1980). 
The alluvial bottomlands zone includes the active floodplain (marked by ponds and abandoned channels of Big Cypress Bayou), as well as alluvial terrace, point bar, and natural levee deposits. Immedialely downstream from Caddo Lake State Park are lacustrine delta deposits (lacustrine, distributary channel and delta mouth bars) that formed within the last 200-500 years or so at the headwaters of Caddo Lake (Albertson and Dunbar 1993:23). Soils bordering Caddo I ake are classified as Cypress clay loam, but fine sandy loam point bar deposits occur on somc of the larger islands in Caddo Lake (Cliff and Peter 1994: 13). Vegetation in the alluvial bottomlands zone includes bottomland hardwoods of oaks, cypress, and sweetgum, with mixed swamp and marsh habitats with cypress, willow, gum, water locust, and button bush (U.S. Department of the Intcrior 1914).

\title{
The Archeology and History of Caddo Lake
}

\author{
Timothy K. Perttula and Bob D. Skiles
}

What do we know about the archeology and history of the Caddo Lake bioregion? The Caddo Lake ecosystem and the Cypress Valley watershed is generally recognized by professional and avocational archeologists as having prehistoric and historic archeological resources of state and national significance. Efforts are underway by the Caddo Lakc Institute to have the Caddo Lake area designated a critical resource zone for archeological planning purposes (see Kenmotsu and Perttula 1993). This part of Northeast Texas and Northwest Louisiana was home to southern-Caddo speakers for thousands of years (and up to 1842). In fact, the Caddo Origin Myth states that the Caddo lived a long time on the lake, with their principal village being called Sha'chidi'ni, or "Timber Hill." Beginning in the early $1800 \mathrm{~s}$, it was also settled by Native Americans (such as the Alabama and Coushatta tribes) and Anglo-American immigrants from Louisiana, Alabama, Tennessee, Mississippi, and other states (Pearson et al. 1994; Dahmer 1995). Each of these cultural groups left behind significant archeological remains that document their history and use of the Caddo Lake bioregion.

While archeological efforts in the Caddo Lake biorcgion have been sporadic over the last 75 ycars or so, over 100 archeological sites have been identificd along its shores and on its islands (Gibson 1969; Albertson and Dunbar 1993; Cliff et al. 1995; Cliff and Peter 1994). Many of these sites contain important research and historical information on the Caddo Indians, the original Native American inhabitants of the region, as well as on the Coushatta and Alabama Indians who immigrated to the area in 1804, and nineteenth century Anglo-American settlers, such as Robert Potter and Harriet Ames (see Perttula 1993b).

Native Amcricans settled in the Caddo Lake bioregion some 12,000 ycars ago, and ranged through its forests and broad floodplains and wetlands (see Figure 2) as mobile hunter-gatherers (for comprehensive discussions of current understandings of the Paleoindian and Archaic archeological record in Northeast Tcxas, see Fields and Tomka 1993 and Story 1990). About 2000 years ago, these Native Americans (ancestral to the Caddo peoples) began to settle down in small camps and hamlets within recognizable territories, where they began to make use of native seeds and tropical cultigens (maize, squash, and later beans), and practiced the art of ceramics. 
From this milieu, about A.D. 800 developed the vibrant and sophisticated Caddo culture, marked by complex and socially-ranked societies with well-planned civic-ceremonial centers (Story 1990:325; Perttula 1992:12-18). The prehistoric (addo peoples were traders and prosperous horticulturists, growing maize, beans, and squash as well as starchy and oily seeds such as maygrass, amaranth, and chenopods, and lived in grass- and cane-covered houses in dispersed sedentary hamlets and villages on the Caddo Lake shoreline and along natural levecs and point bar deposits of Big Cypress Bayou and Red River.

The Caddo were also temple and burial mound builders, and these marked the ceremonial and religious places of important priests and chiefs (Perttula 1995). The largest communities and the most important civic-ceremonial centers were primarily located along the major streams--the Red, Arkansas, Little, Ouachila, and Sabine rivers--but several mounds and/or mound groups are known along the shores of Caddo Lake, including Mound Pond \#1 (4IHS12), Mound Pond \#2 (41HS29), and James Bayou ( 6 CD133).

The Caddo developed long-distance trade networks in prehistoric times. Important items of trade were bison hides, salt, and bois d'arc bows, along with copper, stone, turquoise, and marine shell used for gorgets, cups, and dippers, as well as finished objects such as pottery vessels and large ceremonial bifaces (Brown 1983; Story 1990:309).

One of the most ancient trade pathways in North America linked the southern Caddo tribes (Hasinai) with the northern Caddo tribes (Kadohadacho) along the Red River. It is alluded to in the earliest land survey records as the "main Caddo road." This trail was cited by most early surveyors as Trammel's Trace, named for Nicholas Trammcl, who began using the trail about 1816 to smuggle slaves and horses from Spanish Texas into the United States. It is likely that in ancient times this trail passed across what is now the area of Caddo Lake, perhaps in the vicinity (easi) of Caddo Lake State Park.

By Trammel's heyday, the main route appcars to have veered widely to the west of Caddo Lake, perhaps so that equestrian traffic could avoid the waters of the growing lake. Nevertheless, preliminary archival research suggests that a direct route across the lake was still maintained between the North Caddo Village (located on Trammel's Trace halfway between present Marshall and Karnack) and the Kadohadacho (who moved to the area north of the lake about 1795), until the Caddos were supplanted by Anglo-American settlement.

$\Lambda t$ the time of sustained European (Spanish and French) contact with the native Caddo groups in the late 1600s, Caddo peoples lived on the Red River and in East Texas. Europcan populations increased throughout the eighteenth and nincteenth centuries in the Red River valley and in the vicinity of Natchitoches and Nacogdoches, important fur trading centers (see Pcrttula 1992:30-40). Epidemics between 1691 and 1816 greatly rcduced Caddo populations. In 1828, Berlandier (Ewers 1969:106) cstimated the Kadohadacho population living around and in the vicinity of Caddo Lake at only 300 families.

Most early maps and rccords refer to Caddo Lake by its former name "Ferry Lake," an appellation obviously derived from the early ferry operated by James Shenick at the entrance to 
the lake. By 1824, Shenick had established a ferry on an important crossing at a narrows known as Stormy Point. Although privately owned, the ferry was subsidized by the U. S. Indian Agency to facilitate the Texas Caddos and other Indians in reaching the trading post on Caddo Prairie (Pearson et al. 1994:17).

The Caddo continued to live in this part of Northeast Texas until as late as 1842. The Caddo peoples participated in the fur trade, traded guns, horses, and other items to Europeans and other Native Americans, and developed new trade and economic networks: the rcsulting economic symbiosis between the Caddo and Europeans was an important means of acculturation because great quantities of European goods became available to the Caddo (see Gregory 1973).

The last Caddo Indian or Kadohadacho village in the immediate Caddo Lake area was settled about 1800, and this village is thought to have been situated on James Bayou at the upper end of Caddo Lake (Bagur 1992; McCrocklin 1992); the village has not been located archeologically, however. After the cession of Caddoan lands in Louisiana in 1835, and increased Texas settlement, the Caddo pcoples were removed to the Brazos River arca by the U.S. Government and the Republic of Texas in the 1840s. They remained there through the 1850s, where they were placed on the Brazos Indian Reservation in 1855, and then they (about 1,050 Caddo) were removed again to Oklahoma in 1859 (Smith 1995; Swanton 1942).

Although the area was still largely in the control of the Caddos in 1835 , the first land survcys were made in that year for Texas settlers in the general vicinity of Caddo Lake. In February 1838, the General Land Office of the Republic of Texas re-opened for the receipt of land claims. This stimulated a flurry of land surveys in the rich agricultural lands of the Shelby Land District, adjoining and south of Caddo Lake, that was organized as Harrison County only two years later. The coincidence of Shreve's clearing of the Red River Raft in 1835 and the independence of Texas the following year, opencd the floodgates of $\wedge$ nglo-American emigration to Texas.

Among the vanguard of the earliest Anglo-American arrivals in the Caddo Lake area werc the land surveyors. John S. "Rip" Ford, in later ycars becoming a captain of the Texas Rangers and serving as mayor of Austin, was then working as a surveyor. 1n his memoir (Oates 1987), Ford wrote one of the few descriptions of the Caddo Lakc vicinity that elucidates the period of transition from "Indian country" to frontier settlements. Bccause of the rarity of descriptions from this period, the poignancy of Ford's account, and important information concerning the settlement of Port Caddo and Robert Potter, the first Anglo-American settler on Caddo Lake, a lengthy excerpt in Ford's own words is warranted:

[In 1838] Richard Hooper [District Survcyor] of Shelby County appointed the writer deputy surveyor. [My] district was in Harrison County. The country was full of Indians. Captain Jack Graves, a very clever and hospitable gentleman from Alabama, had settled on Eight Mile Creek ... He had a certificate for a lcague of land which he wished to have located on the land surrounding the Big Spring [Caddo] Village. 
This point was inhabited by Caddo Indians. They were leaving home for up the country, as they said, to hunt. Ford, out of sheer greenness, set his compass and explained to them the object of his mission into their hunting grounds and villages. The surveying party built large fires, put on no guard, and acted like other inexperienced simplctons would. Within a radius of twenty miles there were three or four Indian towns..

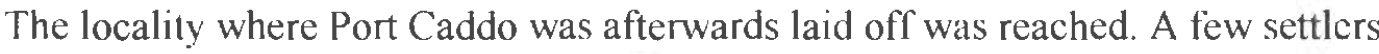
were nestled around it. They obtained supplies by hauling on wagons from Shreveport and by flat boats which navigated Lake Caddo.

This body of water was at that time full of fish. In half an hour one could catch enough finc trout or bass for a meal. Alligators were plentiful, and mainly of large size. We killed a good many.

'The next stopping place was Wray's Bluff, a small town not far from the head of the lake. Dr. Sanderson kept a boarding house which he called a hotel. At this place the writer made the acquaintance of Robert Potter, formerly a member of the United States House of Representatives from the state of North Carolina. He was the secretary of the navy in the Provisional Government of Texas. He was a gentleman of fine address and persuasive eloquence. He was much opposed to the occupation of any portion of the territory of Texas by Indians who had emigrated from the United States. Not far from Colonel Potter's residence the Muscogees [Alabama] had a settlement between Lake Caddo and the Red River, including a large part of what was afterward erected into Bowie County. He managed to disseminate his sentiments very generally among the settlers. $\Lambda$ public meeting was called. A speech from Potter caused great excitement. He charged General I louston with being the friend and ally of the very Indians who were depredating upon the frontier settlements. His picture of the hero of San Jacinto, luxuriating in a breech-clout and spreeing on "bust-head," was extremely ludicrous.

To a person in the habit of looking into things without prejudice, it was evident some unstated project was behind this outpouring of indignation. It was developed: the Caddos had gone down to Shreveport to receive their annuity and presents from the United States. Potter wanted the settlers to attack the Indians on their way up country.

The meeting resolved to raise and organize a company. An old gentleman named [Isaac] Ferguson was elected captain. John S. Ford, without any knowledge of the move, was elected first lieutenant. It was deemed inexpedient to enter a protest against the contemplated expedition. A day or two was allowed for preparation, a time and place of rendezvous named. Ford was on hand. He represented to Captain Ferguson and others the dangers likely to arise from the attempt. In the first place we were not apprized of the number of the Indians, and not sure we could whip them. Sccondly, should we be defeated we would ensure measures of 
retaliation. A cruel war of inexpressible horrors would be waged upon a defenceless frontier, and wc had no assurance of help from any quartcr. The government and the people of Tcxas might view the enterprise in the light of plunder. In those days there was hardly a settler from near Sabine to the Sulphur Fork of Red River.

The men agreed, disbanded, and went to their respective homes. If memory is not greatly at fault, Colonel Polter was not at the place of rendezvous. The writer was then quite young, but he had an idea that fire-eating orators arc not often found in the front of battlc. He is now willing to take an affidavit that these gentry are photographed by Shakespeare: "Al the beginning of a feast and the end of a fray suits a keen guest, and a dull fighter."

... The country now constituting Harrison County was a beautiful one in 1838 . The uplands were timbered; the trunks of the trees were straight, usually. Very little undergrowth was met with to impede the progress of the passer-by and to obstruct his view. The creeks were fringed by thickets, sometimes dense. There were some prairics, not large but pretty...

In the scattered scttlements were found ladies and gentlemen of culture and refinement. The rude cabin was no indication of the class of the inhabitcrs.

The only loss sustained from the Indians was the theft of one of our horses from the settlement on Morris Creek. We did not see an Indian after meeting those near Big Spring Village, except the widow of McIntosh, her family and servants.

(Oates 1987:25-28).

Harriet Page and Robert Potter were among the earliest settlers in Harrison County. They first took up residence a short distance north of the Sabine River, on Potter's Creek in 1836, moving to a point on the north side of Caddo Lakc the next year. I larriet Page-Potter-Ames mentioncd in her memoir that when she and Robert moved to Potter's Point in 1837 , the only other people in the arca were Indians (Pearson et al. 1994:33).

Robert Potter becamc involved in the so-called Regulator-Modcrator War, an armed conflict ostensibly between vigilantes (Regulators) and those who sought justicc through the courts (Moderators). The contlict raged for several years, most notably $1840-1843$, throughout the old "neutral zone" (the Shelby Land District; now encompassing the area within the counties of Shclby, Panola and Harrison). Apparently the violent conflict was initiated by fradulent land claims and official misconduct in the Shelbyville area, and sprcad northward. Potter, a leader of the Moderators in Harrison County, was ambushed and gunned down by an armed party at his residence on Potter's Point in 1843. 
$\underline{\text { Port Caddo }}$

Port Caddo was established as a settlement about 1838. By 1850 , it had a population of at least 50, including four merchants, three grocers, and a tavern. The Texus Republicun carried advertisements for two steamers that year, the Caddo, which could carry 1550 bales of cotton, and the Monterrey, which could make the run to New Orleans in 15 days. Besidcs Marshall, Port Caddo was the only settlement to develop in antebellum I Iarrison County that could be described as a town (Campbell 1983:24, 85).

Harrict Potter noted that the first steamboat to enter Caddo Lake was chartered by her brother and James Rieves to reach Potter's Point. Although Harrict did not specify the year, this must have been in the late 1830s at the earliest (Pearson et al. 1994:33). Others have suggested that steamboats reached Port Caddo by 1836 , but this would be inconsistent with Harriet $\wedge$ mes' testimony (Pearson et al. 1994:34). By 1840, though, steamboat traffic had become common on Caddo Lake.

In his Map and lexcription of Texas compiled in 1840, Francis Moore stated that "Small steamboats are almost constantly plying between the shores of this lake and the portion of the Red River bclow (Pcarson et al. 1994:32). Doubtlessly, boats had docked at Port Caddo for some years before the stcamboat advertisements began listing it as a destination. The earliest advertisement found was for the Bois d'Arc, a 182-ton sidewheeler that left New Orleans on 23 May 1844, with Alexandria, Natchitoches, Shreveport, and Port Caddo listed as destinations. Port Caddo continued to be listed as a destination in steamship advertisements until 1866 (Pearson el al. 1994:34).

\section{Excavation of the Suspected Grave Feature}

Scope of the Excavation

Fxcavation of the suspected grave feature was begun and completed on the Saturday prior to the Discovery Day event, by the student participants of the Caddo Lake Scholars Program, under the supervision of the Principal Investigator. Among the "mentors" assisting students with the excavation (and also pitching in with lots of "hands-on" effort) were: Dr. Herman ("Doc") Gibson, Professor of Anthropology, Wiley College; Dr. David Bieler, Professor of Geology, Centenary C'ollege; and, Mr. Ray Hubbard III, and Mrs. Velicia Hubbard, Archeologists, U.S. Forest Service, National Forests and Grasslands in Tcxas. In addition to those already named, Mr. Bo Nelson and Mr. Mike Turner cooperated in presenting interpretive tours of the excavation site on Discovery Day.

The rectangular concrete border of the featurc was defined as the arbitrary boundary of the excavation unit. Fxcavation was planned within the featurc until evidence was recovered to determine whether or not the feature represented a grave, or until a sterile and undisturbed soil stratum was reached. Furthermore, it was planncd to terminate the excavation upon the discovery 
of any identifiable human bone (or skeletal fragments) within the excavation units, or other evidence that strongly suggested that the feature represented a grave.

\section{Description of the Feature}

When initially discovered the fcature was situated within a dense thicket, the understory of a pine forest, at the edge of the park road (Figure 3). It was observed as a rectangular border or curbing of molded concrete flush with the ground surface. The concrete border measured 12.5 $\mathrm{cm}$ in average width, and formed a rectangle $2.5 \mathrm{~m} \times 1.36 \mathrm{~m}$ in outside dimensions (Figure 4). The concrete border enclosed a shallow $(20 \mathrm{~cm})$ depression near the concretc border and decpening to about $30 \mathrm{~cm}$ in depth in the central portion. There was a deeper pit, that had been dug within the depression, that extended to a depth of about $45 \mathrm{~cm}$ below the surrounding surface. The length of the rectangular feature was oriented roughly parallel with the road, which runs approximately north-south. Located along the west edge of the feature was a large pile of clay, apparently backdirt that had been dug some months before, from the pit in the center of the feature.

It is understandable that local folks who happened upon the feature while visiting the park would interpret it as an abandoned grave. Thc concrete rectangle closely resembles the formed concrete borders that were built to surround many individual and family grave plots in the rural ccmeteries of northeastern Texas, beginning after the turn of the 20th century. The common use of concrete and this type of border, though, dates from a much later time than the pcriod when Port Caddo was in existence. Impressions on the faces of the concrete border indicated that it had been constructed with forms built of planed lumber, further suggesting a time for construction after the demise of Port Caddo. Although unlikely to be related to Port Caddo, it could not be determined from visual inspection whether or not the feature represented a grave border. Only excavation could make that determination.

The north end of the border (including the northwest corner and a short section west of the corner) was the only portion of the concrete that remained completely intact and in sifu. The remainder of the concrete border had been broken into several pieces slightly tilted and/or displaced from their original positions. This type of damage could have resulted from the passage of hcavy equipment (e.g., a tractor, loaded truck, or bulldozer) over the feature, or alternatively, from progressive natural erosion of the edges of the depression that undercut the ground supporting the surrounding concrete border. It is possible that the damage resulted from a combination of both causes.

\section{Excavation Methods}

The first work undertaken was the trimming of the tree limbs, rcmoving the surrounding thicket and completely removing the vegetation from within the concrete border (Figure 5). Thereafter, the surface layer of pine straw and leaf mould was removed and screened. All excavated material was manually screened through $1 / 4$ " hardware cloth at two portable screening stations set up about $2 \mathrm{~m}$ away from the feature (Figure 6). 


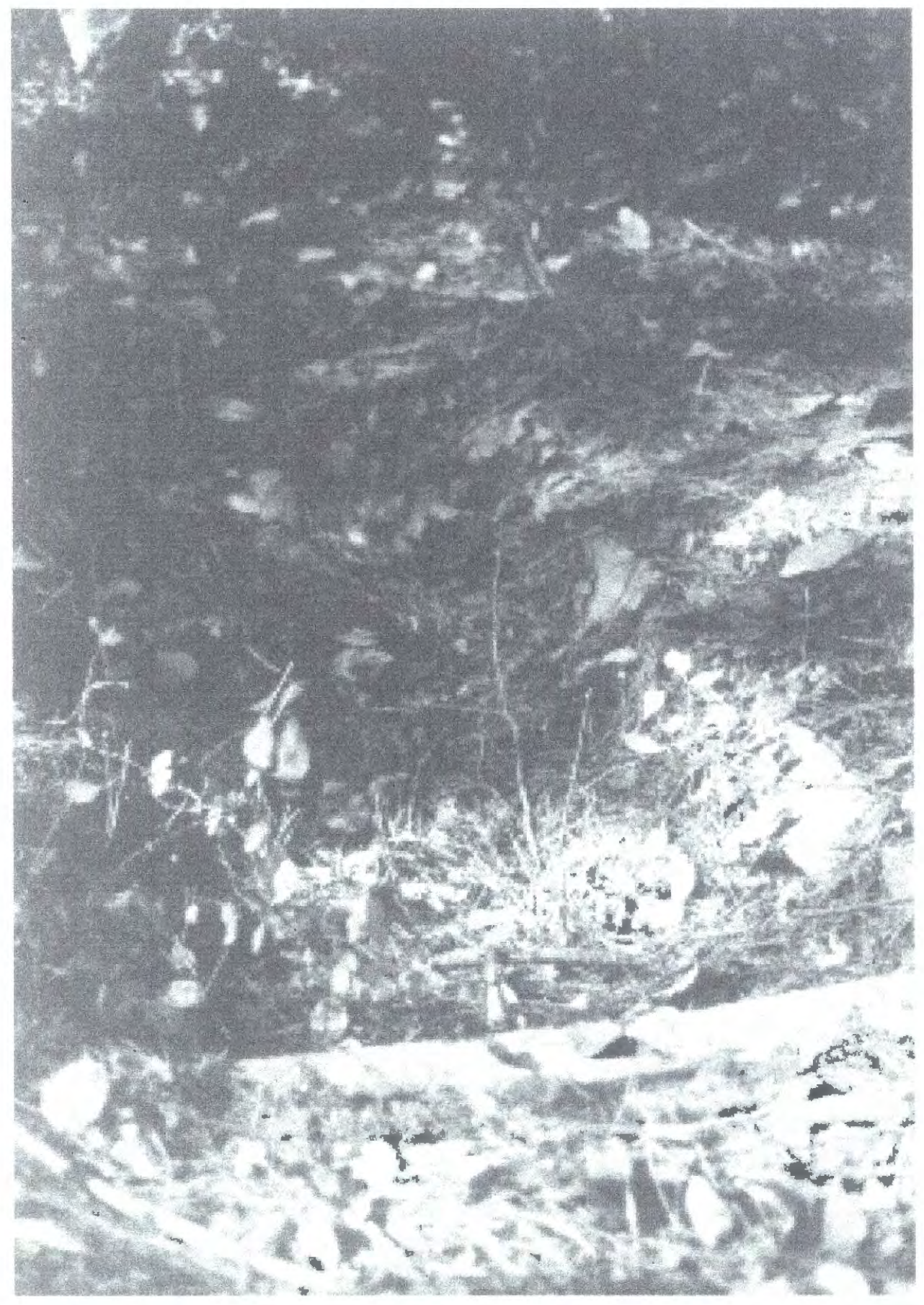

Figure 3. Concrete bordered feature before removal of vegetation. 


\section{Ambur Emery
act. $16,19 \% 3$}
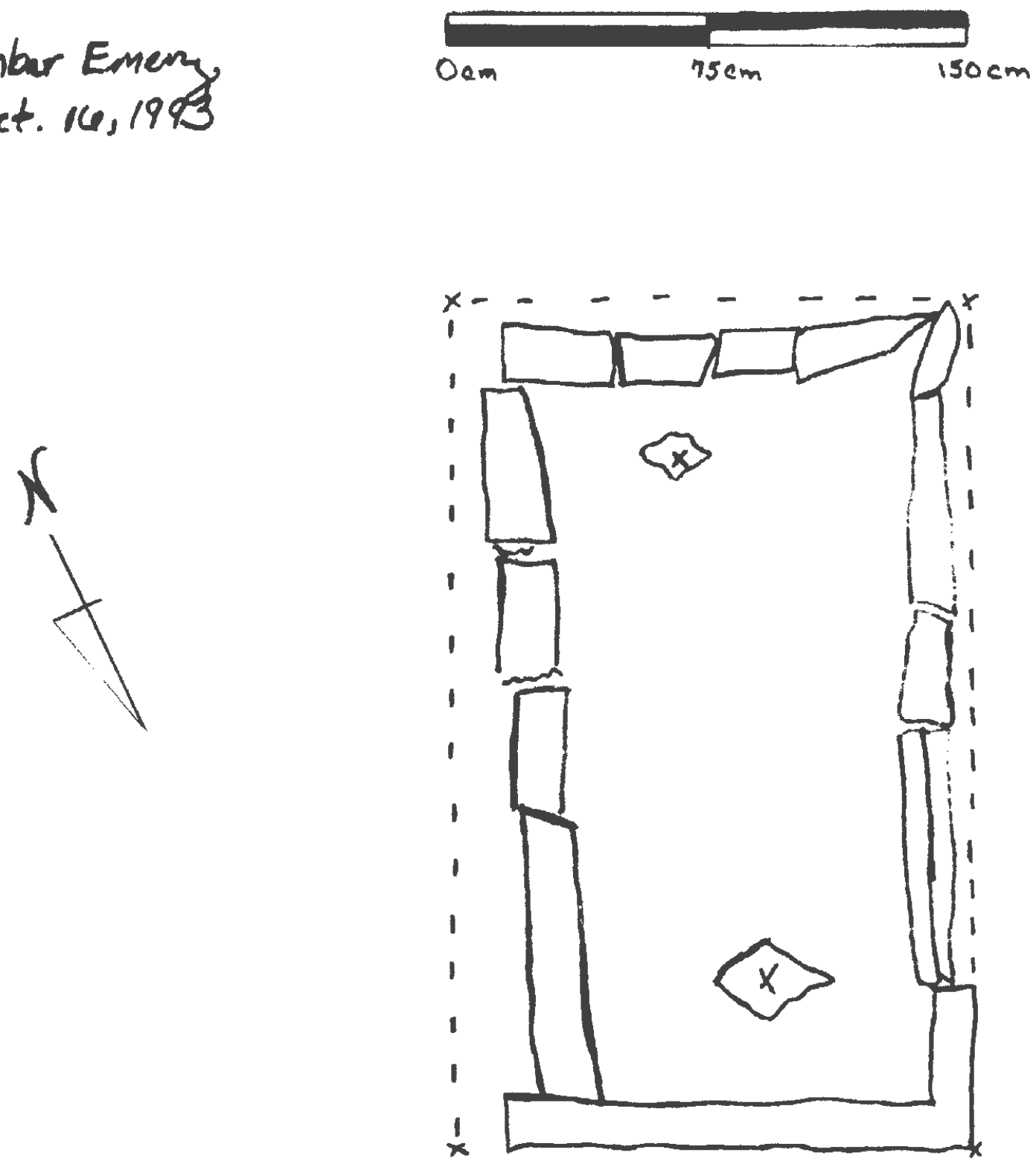

Figure 4 . Scale drawing of the concrete border surrounding the feature. 


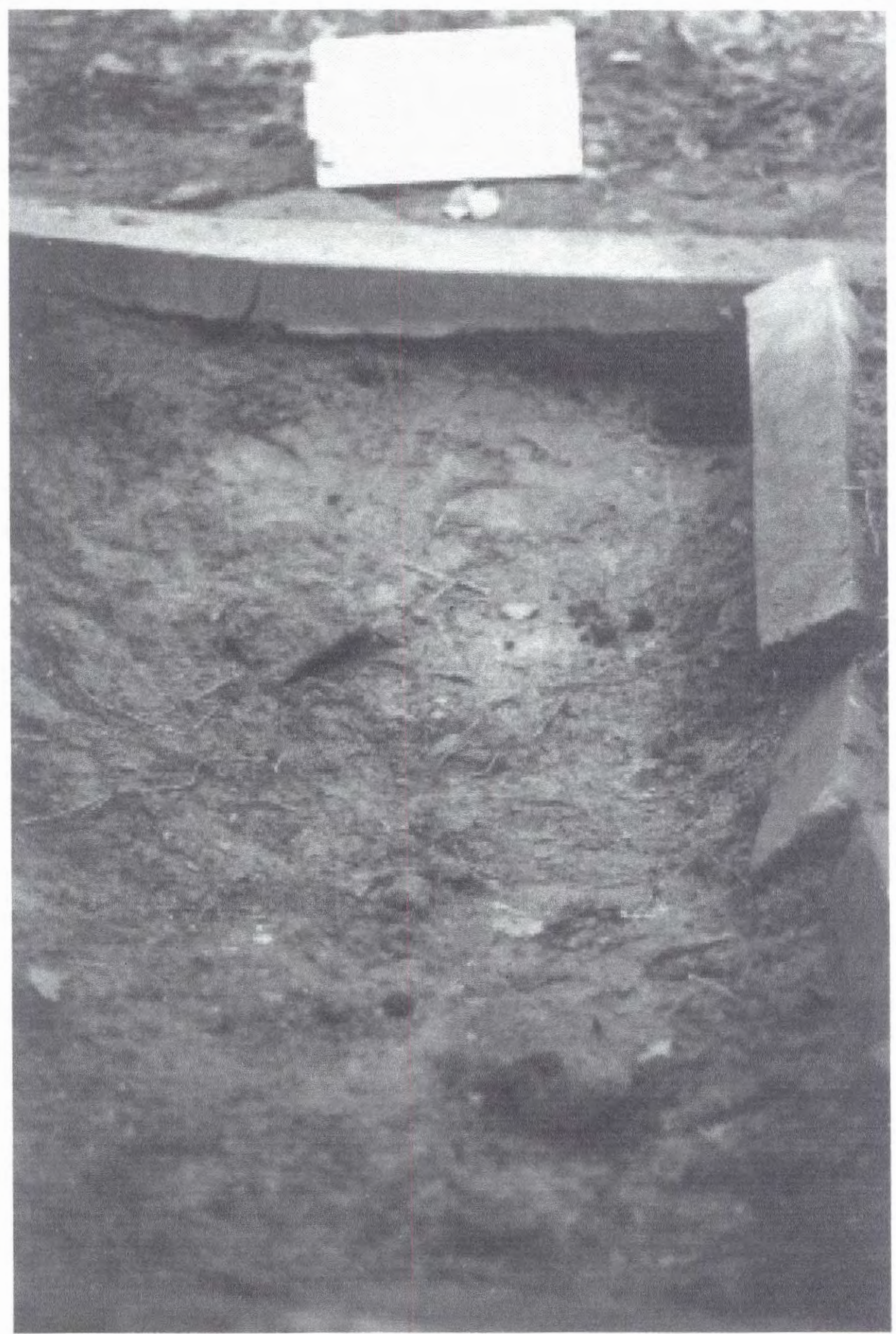

Figure 5. View of feature before excavation and after clearing away vegetation. 


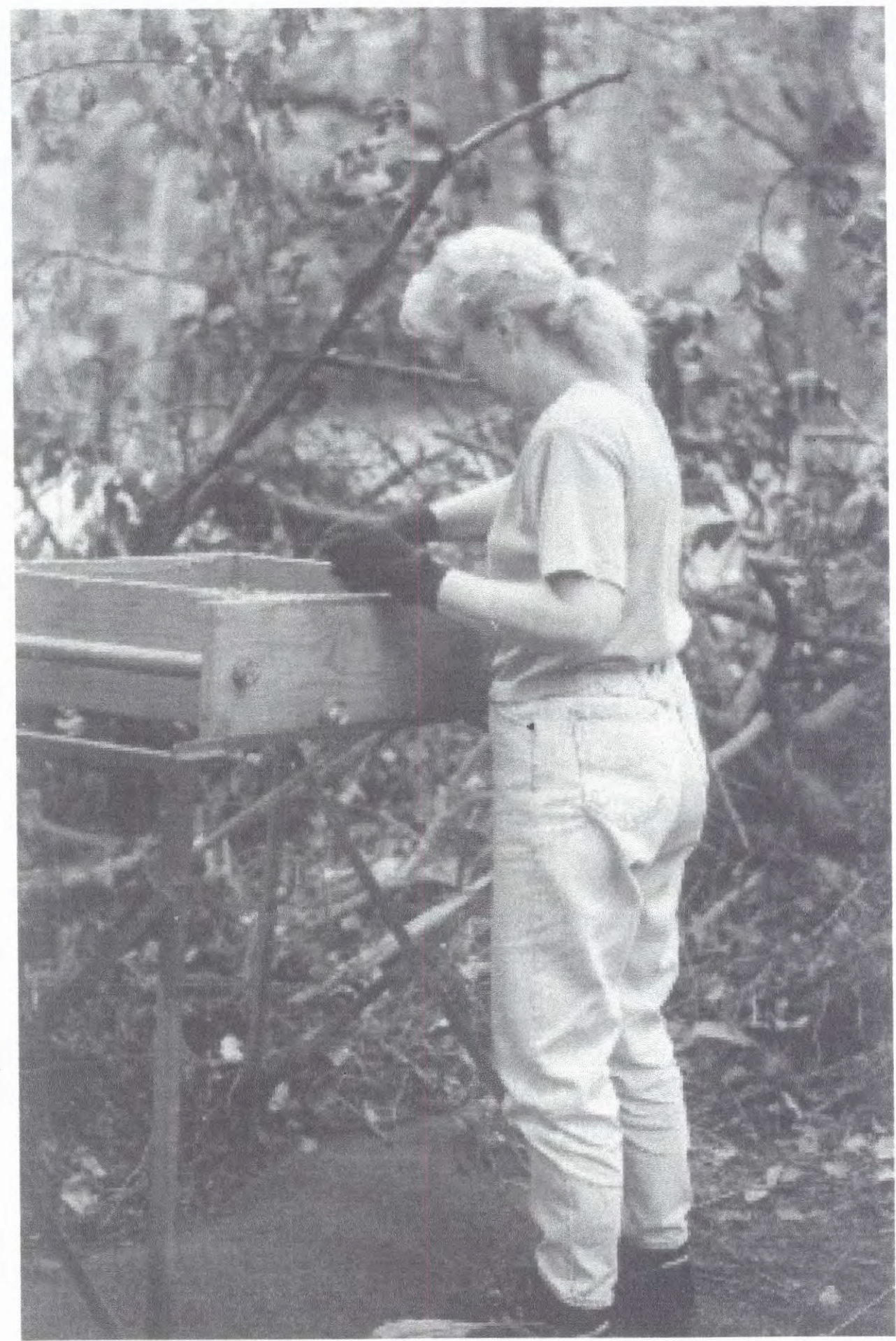

Figure 6. Student volunteer screening matrix from excavation of feature. 
The highest point of the concretc border, the northwest corner, was chosen as a datum and assigned the arbitrary elevation of +90.00 meters. Elevations within the excavation unit were determined by pulling a level line from this point (Figure 7). A scalc drawing of the feature was made (Figure 8, also see Figure 4) and detailed notes were taken as the excavation progressed. Numcrous color photographs and slides were taken of the feature before, during, and after excavation (Figure 9).

After removal and screening of the loose (and sterile) surfacc laycr of humus, a dark brown sandy loam surface was exposed. This surface was troweled smooth to chcck for the appearance of any sub-features. $\Lambda t$ this point, the only sub-feature evident was the roundish pit about $50 \mathrm{~cm}$ in diameter near the center of the depression, representing a former pothole. The fill of this pit was loose and moist (thus appearing darker) by comparison with the surrounding matrix, and contained mottles of the underlying red sandy clay B-horizon and abundant decaying humus. The pothole had apparently been left open, and its fill was derived mainly from erosion of the surrounding matrix.

All the area within the concrete border was treated as a single excavation unit. Excavation was initially planned to be in arbitrary $10 \mathrm{~cm}$ levels using the surface of the feature fill at the northwest corner as a reference plane. However, it was determined soon after beginning excavation that the underlying clay B-horizon would be reached in the first lcvel over much of the feature area. Consequently, due to the shallowness of the fill, it was decided to excavate all the featurc fill as a single level. The thickness of the level varied from about $11-15 \mathrm{~cm}$ around the inner edges of the concretc border to only $1-2 \mathrm{~cm}$ in the center of the depression around the large pothole.

After completing excavation of the fill to the top of the B-horizon, the surfacc was carcfully troweled and examined for features. None was detected. Due to the paucity of recovered artifacts, and to improve the definition between the fill and underlying B-horizon (which was barely reached in some parts of the excavation unit) another level was excavated. The second level was $10 \mathrm{~cm}$ in thickness and completely sterile. Whcreas the first level had been excavated mainly by troweling, the second level was excavated completely with flat shovels.

After completing excavation of the second level, the floor of the excavation was troweled again to search for fcatures, and to take final photographs (see Figure 9). Two generally round areas of dark staining containing diffusc bits of charcoal were noted near each end of the concrete feature. The origin of these two anomalies could not be determined with certainty, although they were too irregularly shaped and indistinct to have been postholes. It is likely that they represented burnt-out roots of small trees or shrubs that had once grown inside the feature. Additionally, the remaining fill in the pothole was troweled out and screened prior to taking the final photograph. The pothole was found to extend only about $3-5 \mathrm{~cm}$ further below the base of the second excavation level. The elevation at the bottom of the pothole was $+89.55 \mathrm{~m}$, or $45 \mathrm{~cm}$ below datum, the deepest point in our excavation. The floor of the second cxcavation level had an average elevation of $+89.58 \mathrm{~m}$, or $42 \mathrm{~cm}$ below datum. 


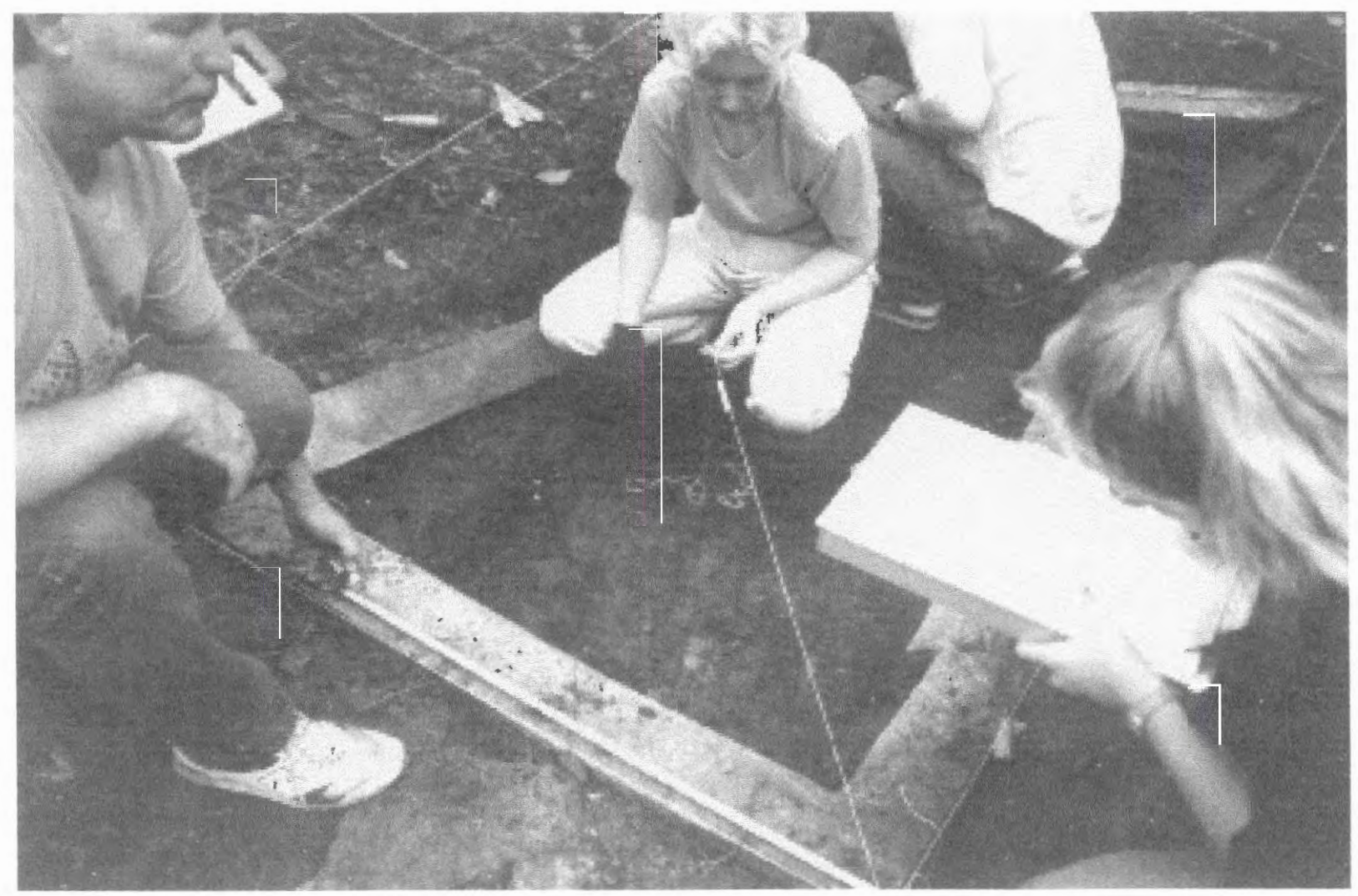

Figure 7. Student and mentor volunteers mapping the excavated feature. 


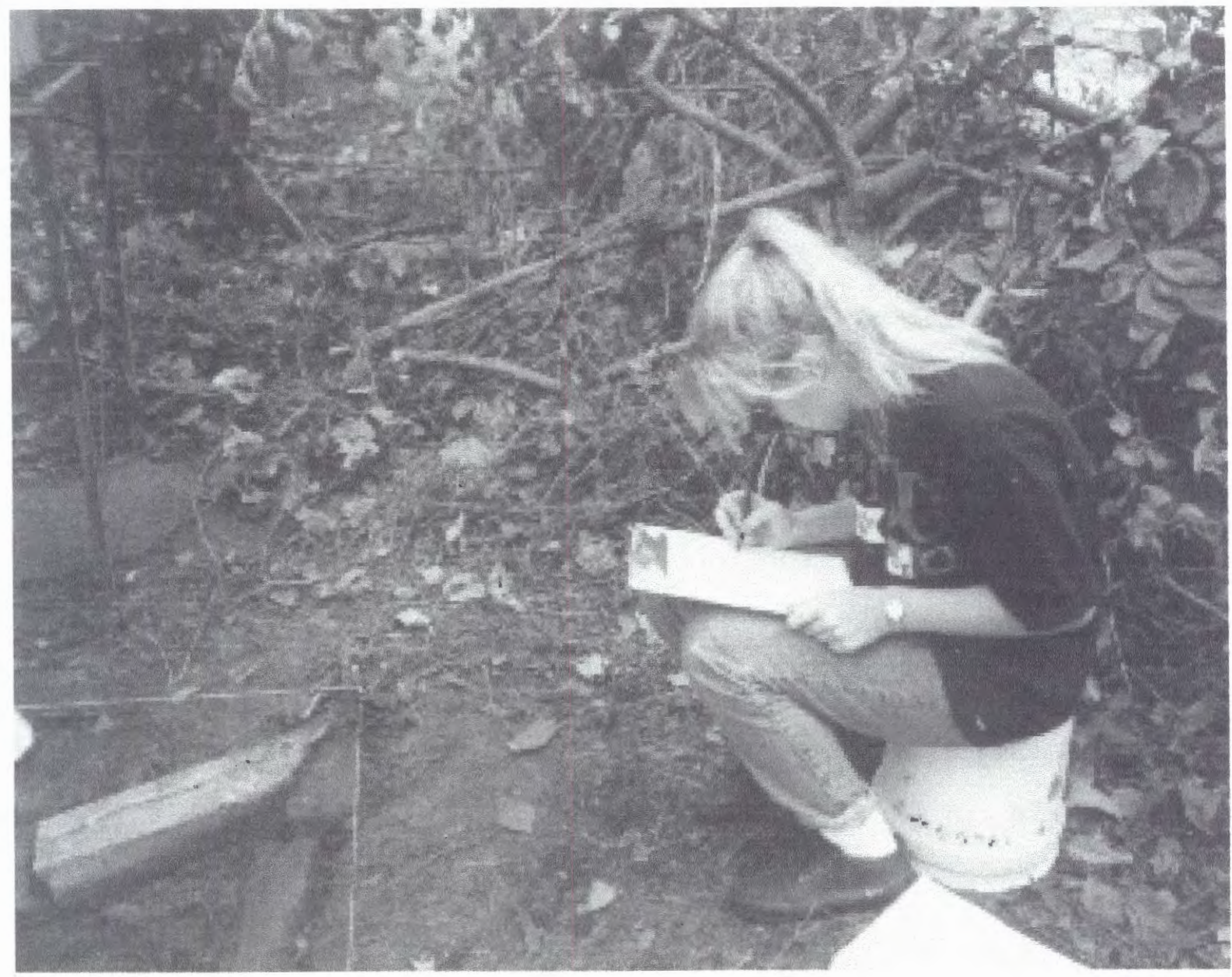

Figure 8. Student volunteer making a scale drawing of the excavated feature. 


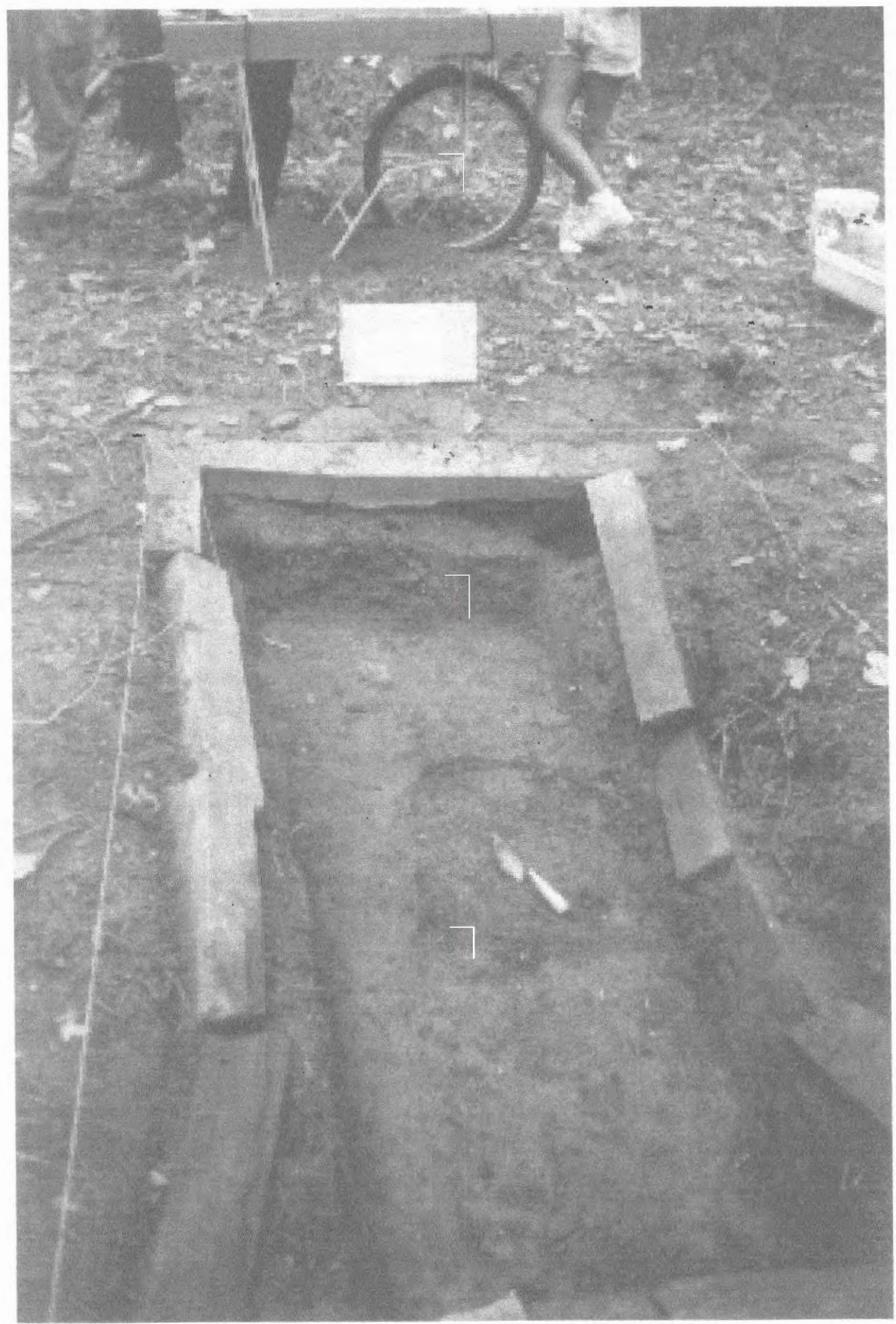

Figure 9. Photograph of the feature after completion of excavation. 
The excavation unit was left open for the ensuing public cvent planned for the following weekend. The backdirt pilc from the pothole was screened as a demonstration of archeological techniques during the educational tours. Texas Parks and Wildlife Department personnel backfilled the excavation unit after conclusion of the Discovery weekend events and tours.

\section{Results of the Excavation}

One bent $16 \mathrm{~d}$ common round wirc nail, a $60 \mathrm{~cm}$ length of heavily corroded stcel (baling?) wire (broken into several shorter pieces), thrce sherds of modern bottle glass, a few small fragments of concrete (likely broken from the surrounding border), and several tiny bits of charcoal $(<1 \mathrm{~g})$ were the only artifacts recovered from the excavation. Of the few artifacts, only the nail and concrete fragments can be presumed to have been directly associatcd with the fealure; the baling wire and bottle glass may simply be incidental rubbish, perhaps discards from the adjacent road. A lone nail manufactured somctime after 1890 offers little in the way of interpretive possibilities, but simply adds weight to the assumption that the construction of the feature must have long post-dated the period when Port Caddo was occupied.

Notwithstanding a paucity of artifacts, our excavation answercd one paramount question that had been posed about the function of the feature: "Was it a grave?" Our excavation clearly demonstrated that the feature was not and had never been a grave. But if not a grave, then what was the feature? The rectangular concretc feature likely represents the foundation or wall footings for a small tool, storage, or utility shed associated with the original Civilian Conservation Corps (CCC) construction of the Caddo Lake State Park facilities. It is located immediately across the road from several of the original buildings and may have been associated in some manner with their construction and operation. It is unlikely that a building meant for temporary use would have becn constructed with a concrete foundation. It is more likely to have been a type of utility house (e.g., a pump house) which through time was no longer needed, and was then abandoned or removed.

Although they have not been researched, archival records offer the greatest hope of further elucidating the function of this feature. It is not uncommon for CCC construction records to contain a site plan that details the locations, dimensions and functions of all structures. Hopefully the CCC construction records for Caddo Lake State Park are still extant in either state or national archives. 


\title{
Archeological Reconnaissance in Caddo Lake State Park
}

\author{
Bo Nelson, Mike Turner, and Timothy K. Pertlula
}

As part of the Caddo Lake Institute's investigations at Caddo Lakc State Park (CISP), a reconnaissance level archeological survey was conducted on CLSP lands in 1993 and 1994. The purpose of the reconnaissancc survey was simply to identify prehistoric and historic archeological sites that would be worthy of designation as State Archeological Landmarks under the Antiquities Code of Texas. Thus, our survey cffort consisted solely of examining selected landforms within the CLSP judged to have a moderate to high potential to contain archeological sites: the crests and toe slopes of upland ridges.

Because of the heavily forested terrain within the CLSP, where surface visibility is virtually nil, we used shovel testing to locate buricd archeological deposits. Shovel tests were judgmentally placed, and were approximately $30 \mathrm{~cm}$ in diameter. Shovel test depths varied depending upon the depth of the clay B-horizon, but ranged between ca. $30-83 \mathrm{~cm}$ below surface; the deeper shovel tests occurred on landforms where the sandy A-horizon was more than 1 meter in thickness, and the B-horizon could not be reached. The matrix from cach of the shovel tests was screened through 1/4-inch mesh hardware cloth, and all recovered artifacts were collected for analysis and eventual TPWD curation.

When archeological sites were identified (either in shovel testing or from archeological materials visible on the surface), between 1-4 shovel tests were excavated to help define site limits, and to retrieve artifacts that would help us assess the age and occupational charactcr of the sites as well as their contextual integrity. Sites were recorded on standard State of Texas Site Data Forms (submitted under separate cover to the Department of Antiquities Protection, Texas Historical Commission, and the Texas Parks and Wildlife Department), and site form sketch maps were used to place shovel tests within the site limits, and depict natural and cultural features.

\section{HS549}

This multicomponent site is on the slopes and crest of a wooded ridge ( 300 feet amsl), about 250 meters from a small tributary of Big Cypress Bayou, and 200 meters south of the CLSP boundaries. The ridge is currently being mined for clay, and this activity has exposed prehistoric and historic artifacts over a 3000 square meter area at the south end of the barrow pit. As surface visibility was good adjacent to the clay pit, no shovel tests were excavated at $41 \mathrm{HS} 549$.

Prehistoric artifacts observed on the site surfacc included: a ferruginous sandstone bi-pitted stone, several pieces of chert, petrified wood, and hematite lithic debris, and a chert tested cobble. Although the age of the prehistoric component is unknown, the occurrence of petrified wood and hematite (both locally available) in the lithic debris suggests that 41HS549 was used sometime during the Archaic period 
Three nineteenth century English whiteware sherds werc noted on the slope above the clay pit. Onc was a small body sherd with a deep blue transfer print with part of a floral motif (estimated to date from ca. 1830-1860), while the other two were rims of blue shell-edged plates. The first has an cven scalloped rim, while the other has an unscalloped rim with short painted lines. According to Hunter and Miller (1994:Plate V), scalloped rim shell-edged plates (mainly of pearlware) werc manufactured between ca. 1810-1835, and the unscalloped shell-edged plates with painted lines date from ca. 1860-1890.

While the sample of historic ceramic artifacts is quitc small, they do suggest that site 411 IS549 datcs from Antebellum times. It may be part of the town of Port Caddo, a small port on this part of Caddo Lake in operation by the late 1830s (Pearson et al. 1994:33-34). Consequently, the historic archeological component has the potential (if any in situ archeological deposits remain at the site) to contain important information on the frontier and Republic of Texas settlement of the Northeast Texas region and may warrant designation as a State Archeological Landmark.

Provided the permission of the landowners call be obtained, we recommend that a program of systematic shovel testing be compleled around the clay borrow pil to ascertain if any intact historic and/or prehistoric archeological deposits remain at 4lHS549. These archeological investigations should proceed in concert with archival studies to help determine the ethnic and temporal affiliation of the site occupants.

\section{$\underline{41 H S 581}$}

A small ( $<1000$ square meters) prehistoric site was located by shovel testing along the tip of a steeply sloping and eroded ridge between 300-320 feet amsl, just west of the main paved road through the CLSP. The ridge has sandy sediments more than 1 meter in thickness, and the two shovel tests excavatcd on 41 HS581 penetrated to ca. $83 \mathrm{~cm}$ below surface (bs).

Prehistoric artifacts and charred nutshells were recovered from $10-75 \mathrm{~cm}$ bs in both positive shovel tests. The 8 pieces of lithic debris found include small, non-cortical, flakes of local chert $(n=5)$, fine-grained quartzite $(n=2)$, and chalcedony $\left(n^{-1}\right)$. Shovel test 1 had 7 charred Carya $\mathrm{sp}$. nutshells (found between $60-75 \mathrm{~cm} \mathrm{bs}$ ), and one other nutshcll was collected from shovel test 2; 2 pieces of charcoal were also recovered from shovel test 1.

The recovery of charred nutshells in deep sandy deposits at 41HS581 suggests that cultural features of unknown age may be preserved at this prchistoric site. The few small picces of lithic debris indicate only that the site occupants engaged in lithic manufacturing and/or refurbishing activities.

It is necessary to clarify the contextual integrity of the site's archeological deposit, and better assess its research significance. We recommend that a program of systematic shovel testing and $1 \times 1$ meter test units be developed and implemented to help determine whether site 41 HS581 warrants designation as a State Archeological Landmark. 


\section{$41 \mathrm{HS} 582$}

Site 41HS582 was found just within the boundary fence of the CLSP, northwest of 41HS549. It lies in open woods at an elevation of 220-230 feet amsl on a narrow toe slope.

The site was first recognized because of a prominent chimney fall mound (ca. 30 square meters in area and 1 meter in height) of ferruginous sandstone blocks; a shallow depression about 20 meters to the east may mark a filled-in privy or well (ligure 10). Four shovel tests were excavated in the vicinity of these features to determine if intact historic archeological deposits were present, and to retrieve a sample of material culture remains that could prove informative about the temporal span and occupational character of the site.

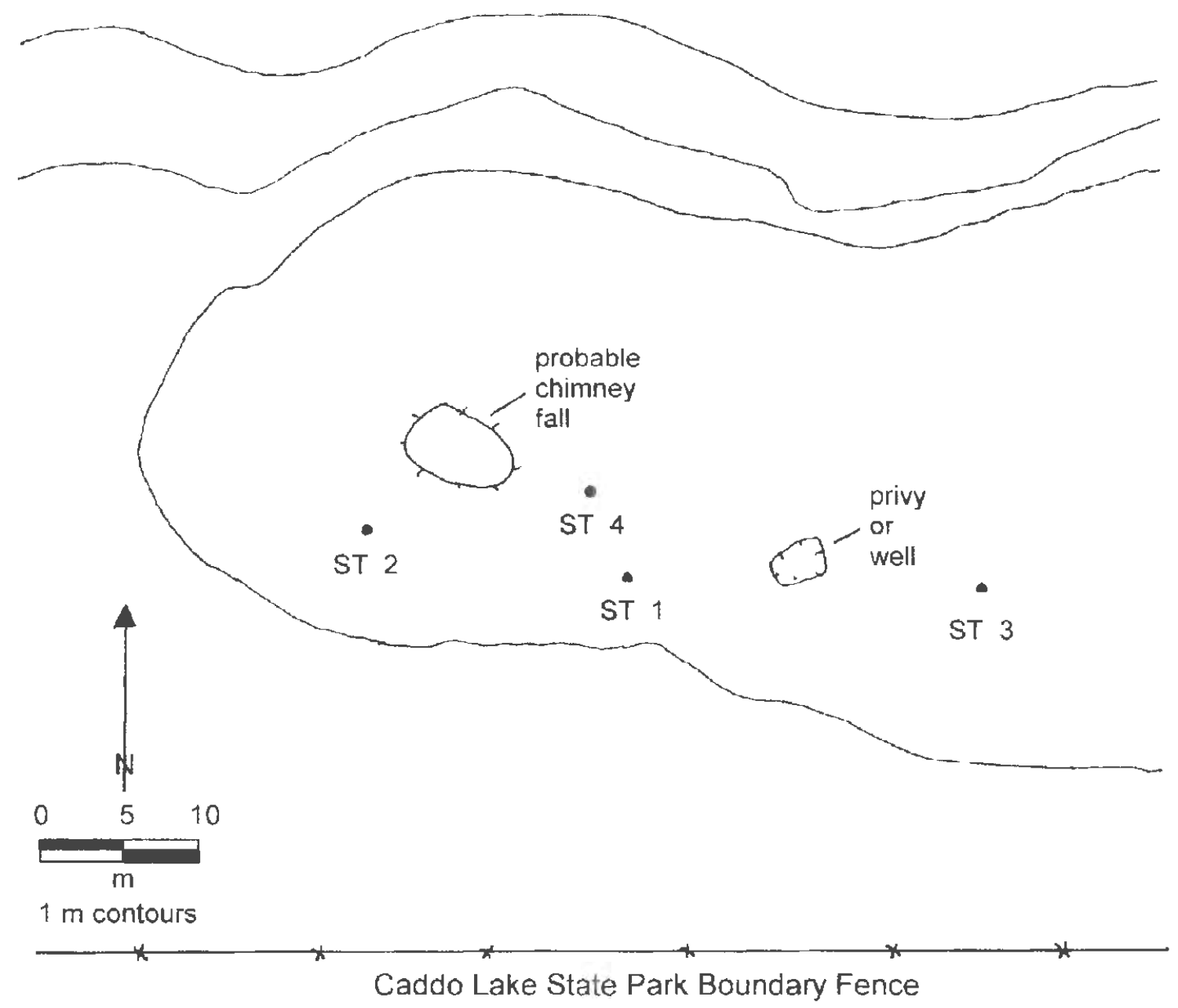

Figure 10. Map of site 41 HS 582. 
Shovel tests 1, 2, and 4 did contain historic artifacts (Table 1) in a dark brown sandy loam deposit between $0-15 \mathrm{~cm}$ (shovel test 2) and 0-35 $\mathrm{cm}$ (shovel test 1) in thickness. Shovel test 1 aclually encountered a $25 \mathrm{~cm}$ thick midden deposit $(0-25 \mathrm{~cm}$ bs) with abundant artifacts and preserved faunal remains, and additional historic artifacts were recovercd from $25-35 \mathrm{~cm}$ bs below the midden.

Table 1. Historic Artifacts from 41 HS582.

\begin{tabular}{|c|c|c|c|c|c|l|}
\hline $\begin{array}{l}\text { Shovel } \\
\text { Test \# }\end{array}$ & $\begin{array}{l}\text { Cut } \\
\text { Nail }\end{array}$ & $\begin{array}{l}\text { Wire } \\
\text { Nail }\end{array}$ & $\begin{array}{l}\text { White- } \\
\text { ware }\end{array}$ & $\begin{array}{l}\text { Bottle } \\
\text { Glass }\end{array}$ & $\begin{array}{l}\text { Stone- } \\
\text { ware }\end{array}$ & $\begin{array}{l}\text { Other } \\
\text { Artifacts }\end{array}$ \\
\hline 1 & 3 & 1 & - & 6 & 1 & 1 fence staple, 6 faunal, 1 window glass \\
\hline 2 & 2 & - & - & - & - & - \\
\hline 3 & 1 & - & 1 & 2 & - & 1 window glass \\
\hline
\end{tabular}

The historic occupation al 4 IHS582 is conservatively estimated to date from ca. $1870-1920$. We base this estimate on: (a) the co-occurrence of cut and wire nails (but with a predominance of cut nails, indicating that the structure at the site was built before 1890 [cf. Jurney 1987]); and (b) the picce of natural clay slipped stoneware (estimated by Lebo [1987] to date from ca. 1875-1915) from shovel test 1 . Consistent with this period of occupation is the recovery of relativcly thin, aqua-colored window glass, and colorless bottle glass.

Because of the preserved features and the midden deposits from a probable historic farmstead, and the age of the occupation, we recommend that this site be formally designated as a State Archeological Landmark. This site can contribute important information from archeological and historical studies on rural lifeways in late nineteenth-early twentieth century Northeast Texas.

\section{HS583}

Site 4 IHS583 is situated on a narrow but prominent ridge 20 meters above, but overlooking, Big Cypress Bayou. The ridge is thickly forested with pines and hardwoods.

A single shovel test was excavated on a fairly level part of the ridge at $41 \mathrm{HS} 583$. Prehistoric and historic artifacts were recovered between $10-45 \mathrm{~cm}$ bs in a gravelly sand A-Horizon. These included a square machine cut nail (8d) and five prehistoric lithic items: 1 small hematite core fragment, 2 petrified wood chips/chunks, and 2 pieces of local lithic debris (red chert and fine-grained quartzite).

At this point, we know little about the integrity or occupational content of the prehistoric and historic components at 41 HS583. Additional shovel testing is warranted along the ridge to gather this information, which will help in assessing the historical significancc of the archeological deposits and in determining whether the site has the potential to warrant State Archeological Landmark designation. 


\section{References Cited}

Albcrtson, Paul L. and Joseph B. Dunbar

1993 Geomorphic Investigation of Shreveport to Daingcrficld Navigation Project. Technical Report GL-93-31. U.S. Army Engineer Waterways Experiment Station, Geotcchnical Laboratory, Vicksburg.

Bagur, Jacques

1992 The Caddo Indian Village. Caddoan Archeology Newsletter Volume III, No. 3, pp. 15-16.

Brown, James A.

1983 Spiro Exchange Connections revealed by Sources of Imported Raw Matcrials. In Southeastern Natives and Their Pasts, edited by Don G. Wyckoff and Jack L. Hofman, pp. 129-162. Studies in Oklahoma's Past No. 11. Oklahoma Archeological Survey, Norman.

Campbell, Randolph B.

1983 A Southern Community in Crisis: Harrison County, Texas, 1850-1880. Texas State Historical Association, Austin.

Cliff, Maynard B. and Duane E. Peter (editors)

1994 Archeological Survey of Selccted Portions of the Longhorn Army Ammunition Plant, Harrison County, Texas, 1989-1992. Miscellaneous Report of Investigations Number 38. Geo-Marine, Inc., Plano.

Cliff, Maynard B., Steve M. Hunt, Floyd Kent, Melissa M. Green, and Duane E. Peter 1995 Archeological Survey of 1993-1994 Timber Harvesting Areas, Longhorn Army Ammunition Plant, Harrison Counly, Texas. Miscellaneous Report of Investigations Number 71. Geo-Marine, Inc., Plano.

Dahmer, Fred

1995 Caddo Was... A Short History of Caddo Lake. University of Texas Press, Austin.

Diamond, D. D., D. H. Riskind, and S. L. Orzell

1987 A Framework for Plant Community Classification and Conservation in Texas. The Texas Journal of Science 39:203-221.

Ewers, John C.

1973 The Influence of Fpidemics on the Indian Populations and Cultures of Texas. Plains Anthropologist 18:104-115.

Ewers, John C. (editor)

1969 The Indians of Texas in 1830 by Jean Louis Berlandier. Smithsonian Institution Press, Washington, D.C. 
Fields, Ross C. and Steve A. Tomka, with contributions by Timothy K. Perllula

1993 Hunter-Gatherer Mobility in Northcast Texas. In Archeology in the Lastern Planning Region, Texas: A Planning Document, edited by Nancy A. Kenmotsu and Timothy K. Perttula, pp. 69-95. Cultural Resource Management Report 3. Department of Antiquities Protection, Texas Historical Commission, Texas.

Gibson, Jon L

1969 Archaeological Survey at Caddo I,ake, Louisiana and Texas. Contributions in Anthropology, Number 6. Department of Anthropology, Southern Methodist University, Dallas.

Gregory, I Iiram F.

1973 Fighteenth-Century Caddoan Archaeology: A Study in Models and Interpretation. Ph.D. dissertation, Southern Methodist University, Dallas.

I lunter, Robert R., Jr. and George L. Miller

1994 Linglish Shell-Fdge Earthenware, Antiques CXLV, No, 3, pp. 432-443.

Jurney, David H.

1987 Cut and Wire Nails: Functional and Temporal Interpretations. In Historic Buildings, Material Culture, and People of the Prairie Margin: Architecture, Artifacts, and Synthesis of Historic Archaeology, edited by David H. Jurney and Randall W. Moir, pp. 83-96. Richland Creek Technical Series, Volume V. Archaeology Research Program, Institute for the Study of Farth and Man, Southern Methodist University, Dallas.

Kenmolsu, Nancy A. and Timothy K. Perttula (editors)

1993 Archeology in the Eastern Planning Region, Texas: A Planning Document. Cultural Resource Management Report 3. Texas Historical Commission, Department of Antiquities Protection, Austin.

l.ebo, Susan A.

1987 Local Utilitarian Stonewares: A Diminishing Artifact Category. In Historic Buildings, Material Culture, and People of the Prairie Margin: Architecture, Artifacts, and Synthesis of Historic Archaeology, edited by David H. Jurney and Randall W. Moir, pp. 121-142. Richland Creek Technical Scries, Volume V. Archaeology Research Program, Institute for the Study of Earth and Man, Southern Methodist University, Dallas.

McCrocklin, Claude

1992 An Intermediate Report on the James Bayou Survey, Marion County, Texas: A Search for Caddo Village. Caddon Archeology Newsletter, Volume III, No. 3, pp. 17-20.

Oates, Stephen B. (editor)

1987 Rip Ford's Texas. University of Texas Press, Austin. 
Pearson, Charles E., Jacques Bagur, and James Dufr

1994 Identification and Analysis of Historic Watercraft in the Shreveport, I.ouisiana, to Daingerfield, Texas, Navigation Project. Coastal Environments, Inc., Baton Rouge.

Perttula, Timothy $\mathrm{K}$.

1992 "The Caddo Nation": Archaeological and Ethnohistoric Perspectives. University of Texas Press, Austin.

1993a The Caddo Lake Scholars Program Seminar and What It Means for the Protection of Caddoan Archeological Resources. Caddoan Archeological Newsletter Volume IV, Number 2, pp. 2-4.

1993b Archaeological lnvestigations at the Robert Potter and Harriet Amcs Cabin (41MR51) on Potter's Point, Caddo Lake. Notes on Northeast lexas Archaeology, No. 2:14-25.

1995 The Archeology of the Pineywoods and Post Oak Savanna of Northcast Texas. Bulletin of the Texas Archeological Society 66, in press.

Peter, D. E. and C. Stiles-I Janson

1990 An Asscssment of the Cultural Resources within the Longhorn Army Ammunition Plant, Harrison County, Texas. Miscellaneous Report of Investigations No. 3. Geo-Marine, Inc., Plano.

Shellman, Dwight K., Jr.

1993 Overview of Unifying Themes. In The Caddo Lake Scholars Seminar and Awards Presentations Bricfing Booklet, pp. 70-74. Isis Fund, Caddo I ake Institute, Last Texas Baptist University, Wiley College, Stephen F. Austin State University, and Uncertain Nudubon Society of Texas and Louisiana.

1995 A Mission Statement of Caddo Lake Institule regarding its participation in the 1995 Caddo Conference. Paper presented at the 37th Caddo Conference, Austin, Texas.

Smith, F. Todd

1995 On the Convergence of Empire: The Caddo Indian Confederacies, 1542-1854. Texas A\&M University Press, College Station.

Story, Dee Ann

1990 Culture History of the Native Americans. In The Archeology and Bioarcheology of the Gulf Coastal Plain, by Dee Ann Story, Janice A. Guy, Barbara A. Burnett, Jerome C. Rose, Martha D. Freeman, D. Gentry Steele, Karl J. Reinhard, and Ben W. Olive, pp. 163-366. 2 Vols. Research Series No. 38. Arkansas Archcological Survey, Fayetteville.

Swanton, John R.

1942 Source Material on the History and Ethnology of the Caddo Indians. Bulletin 132. Bureau of American Ethnology, Smithsonian Institution, Washington, D.C. 
U.S. Department of the Interior

1914 Examination of Ferry (Caddo) Lake. 3 Vols. National Archives, Washington, D.C. 